\section{ASPEK HUKUM PEMBERIAN IZIN USAHA BISNIS PERTAMBANGAN MINERAL DAN BATUBARA DI INDONESIA ${ }^{1}$ \\ Oleh : Christo Viki Lumintang ${ }^{2}$ \\ Ronald J. Mawuntu ${ }^{3}$ \\ Delasnova S. S. Lumintang ${ }^{4}$}

\begin{abstract}
ABSTRAK
Tujuan dilakukannya penelitian ini adalah untuk mengetahui bagaimana aturan hukum terhadap pengelolaan pemberian ijin usaha bisnis pertambangan mineral dan batubara di Indonesia dan bagaimana implementasi terhadap pemberian izin usaha bisnis pertambangan mineral dan batubara di Indonesia, yang dengan menggunakan metode penelitian hukum normatif disimpulkan: 1. Pengaturan hukum terhadap pengelolaan pemberian ijin usaha bisnis pertambangan mineral dan batubara di Indonesia, melalui Pasal 1 (7) UU No.4 Tahun 2009 tentang Pertambangan Mineral dan Batubara bahwa, berkaitan dengan Izin Usaha Pertambangan (IUP), juga melalui Pasal 6 Peraturan Pemerintah No.23 Tahun 2010 tentang Pelaksanaan Kegiatan Usaha Pertambangan Mineral dan Batubara (dikenal sebagai PP 23 Tahun 2010) yang mengatur bahwa IUP diberikan oleh Menteri, Gubernur, atau Bupati/Walikota sesuai dengan kewenangannya. 2 . Implementasi terhadap pemberian izin usaha bisnis pertambangan mineral dan batubara di Indonesia yaitu melalui pemberian izin untuk melakukan usaha pertambangan kepada orang pribadi atau badan yang diberikan oleh Pemerintah Pusat dengan berkoordinasi dengan Pemerintah Daerah. Izin Usaha Pertambangan diberikan dalam bentuk surat keputusan Izin Usaha Pertambangan, yang terdiri atas dua tahap: Izin Usaha Pertambangan Eksplorasi dan Izin Usaha Pertambangan Operasi Produksi.

Kata kunci: pertambangan; mineral dan batubara;
\end{abstract}

\section{PENDAHULUAN}

\section{A. Latar Belakang Penelitian}

\footnotetext{
${ }^{1}$ Artikel Skripsi.

${ }^{2}$ Mahasiswa pada Fakultas Hukum Unsrat, NIM. 16071101557

${ }^{3}$ Fakultas Hukum Unsrat, Guru Besar IImu Hukum

${ }^{4}$ Fakultas Hukum Unsrat, Magister IImu Hukum
}

Khusus untuk pemanfaatan potensi sumber daya alam di bidang pertambangan mineral dan batubara di Indonesia, diatur melalui Undang-undang No. 4 Tahun 2009 tentang Pertambangan, Mineral dan Batubara. Melalui Undang-undang No. 4 Tahun 2009 ini telah diatur bahwa Usaha Pertambangan adalah kegiatan dalam rangka pengusahaan mineral dan batubara, yang meliputi tahapan kegiatan: 1) Penyelidikan umum (prospeksi), 2) Eksplorasi, 3) Studi kelayakan, 4) Konstruksi, 5) Penambangan, 6) Pengolahan dan pemurnian, 7) Pemasaran, dan 8) Pasca tambang (reklamasi). Dengan demikian Usaha Pertambangan dapat dikelompokkan menjadi 2 (dua) macam, yaitu : Pertambagan Mineral dan Batubara. Peran negara yaitu dalam membuat regulasi-regulasi, sehingga pengelolaan Pertambangan ini dapat memberikan manfaat dan dalam koridor yang wajar, artinya tidakakan menimbulkan potensi munculnya bencana baik pada saat maupun setelah dikelola (pasca tambang), dan hasilnya dapat digunakan juga untuk meningkatkan kesejahteraan masyarakat. Untuk teknis pelaksanaan peraturan Pertambangan, Mineral dan Batubara telah dibuat Peraturan Pemerintah (PP) diantaranya PP. No. 23 Tahun 2010 tentang Pelaksanaan Kegiatan usaha Pertambangan, Mineral dan Batubara.

\section{B. Perumusan masalah}

1. Bagaimana aturan hukum terhadap pengelolaan pemberian ijin usaha bisnis pertambangan mineral dan batubara di Indonesia?

2. Bagaimana implementasi terhadap pemberian izin usaha bisnis pertambangan mineral dan batubara di Indonesia?

\section{Metode Penelitian}

Penelitian ini menggunakan metode penelitian yang termasuk jenis penelitian normatif.

\section{PEMBAHASAN}

A. Pengaturan Hukum Terhadap Pengelolaan Pemberian ljin Usaha Bisnis Pertambangan Mineral dan Batubara di Indonesia

Pertambangan Mineral dan Batubara merupakan bidang usaha (bisnis) yang sangat menguntungkan bagi para pengusaha apabila 
dilaksanakan secara tepat. Namun dilain pihak banyak permasalahan yang menyeratai dalam pelaksanaan operasioanal dari investasi di bidang Mineral dan Batubara ini. Dalam proses investasi untuk pembukaan sebuah tambang, tidak jarang pihak investor/perusahaan yang bergerak di bidang Mineral dan Batubara harus berhadap-hadapan dengan penduduk, yang merasa memiliki hak yang sama untuk melakukan penambangan terhadap lahan yang tersedia.

Meningkatnya jumlah penduduk menjadi faktor utama terhadap meningkatnya kebutuhan pemukiman. Juga untuk memenuhi kebutuhan lahan yang semakin lama semakin sempit maka penduduk setempat dengan berbagai cara melakukan perluasan lahan yaitu dengan menambang/mengepras gunung dan perbukitan. Menurut Almaida, (2008) kehidupan di era modern tidak luput dengan industri untuk memproduksi barang/jasa. Semakin pesatnya pertumbuhan kota maka lahan makin terbatas dan kebutuhan lahan untuk industri di kota-kota besar dipenuhi dengan reklamasi dan penambangan mineral bukan logam. ${ }^{5}$

Pemerintah baik pusat maupun daerah memiliki peran yang sangat penting terutama untuk membuat regulasi, agar proses investasi di bidang Mineral dan Batubara dalam prosesnya tidak akan mengalami hambatan atau bermasalah dengan hukum.

Undang-Undang Nomor 23 Tahun 2014 tentang Pemerintahan Daerah, yang bertujuan untuk mendorong lebih terciptanya daya guna dan hasil guna penyelenggaraan Pemerintahan Daerah dalam menyejahterakan masyarakat, baik melalui peningkatan pelayanan publik maupun melalui peningkatan daya saing Daerah. Perubahan ini bertujuan untuk memacu sinergi dalam berbagai aspek dalam penyelenggaraan Pemerintahan Daerah dengan Pemerintah Pusat. ${ }^{6}$

Kewenangan untuk pengelolaan pertambangan dari tingkat pusat hingga

\footnotetext{
5 Almaida, (2008). Upaya Pengolahan Lingkungan Kegiatan Pertambangan.

https://muktiarsandi.wordpress.com/2016/06/15/upayapengolahan-lingkungan-kegiatan...

6 UU Nomor 23 Tahun 2014 tentang Pemerintahan Daerah, Topik tentang Inovasi Daerah. https://www.jogloabang.com/pustaka/uu-23-2014pemerintahan-daerah
}

kabupaten/kota telah diatur dalam UndangUndang Nomor 4 Tahun 2009 tentang Pertambangan Mineral dan Batubara. Dengan adanya dua peraturan tersebut seharusnya semakin memperkuat posisi pemerintah daerah dalam hal ini pemerintah tingkat Kabupaten/Kota. Namun, sangat disayangkan pemerintah Kabupaten/Kota belum memaksimalkan kekuatan hukum ini dalam penegakan upaya pengelolaan pertambangan yang ramah lingkungan. ${ }^{7}$

Kegiatan penambangan yang dilakukan secara ekonomi, mampu mendatangkan keuntungan yang sangat besar yaitu mendatangkan devisa dan menyerap tenaga kerja sangat banyak dan bagi Kabupaten/Kota bisa meningkatkan Pendapatan Asli Daerah (PAD) dengan kewajiban pengusaha membayar retribusi dan lain-lain. Namun, keuntungan ekonomi yang didapat tidak sebanding dengan kerusakan lingkungan akibat kegiatan penambangan yang syarat dengan eksplorasi dan eksploitasi sumber daya alam. ${ }^{8}$

Untuk itu regulasi di bidang perijinan, pengelolaan, penambangan termasuk pasca tambang harus dibuat/diatur dan disupervisi secara ketat oleh pemerintah. Sehingga manfaat yang diharapkan untuk memperoleh devisa, serta meningkatkan kesejahteraan masyarakat sekitar dapat dicapai. Seperti telah diatur pada Pasal 1 ayat (7) UU No. 4 Tahun 2009 tentang Pertambangan Mineral dan Batubara bahwa, Izin Usaha Pertambangan (IUP) adalah izin yang diberikan untuk melaksanakan usaha pertambangan. ${ }^{9}$

Izin Usaha Pertambangan (IUP) merupakan kewenangan Pemerintah terutama dalam pengelolaan pertambangan mineral dan batubara. Pasal 6 Peraturan Pemerintah No. 23 Tahun 2010 tentang Pelaksanaan Kegiatan Usaha Pertambangan Mineral dan Batubara (dikenal sebagai PP 23 Tahun 2010) mengatur bahwa IUP diberikan oleh Menteri, Gubernur,

\footnotetext{
7 Undang-Undang Nomor 4 Tahun 2009 tentang Pertambangan Mineral dan Batubara.

${ }^{8}$ Hasibuan, Puspa Melati. (2006). Dampak Penambangan Bahan GalianGolongan C terhadap Lingkungan Sekitarnya di Kabupaten Deli Serdang. eprints.undip.ac.id/36437/2/Bab_1\%2C2\%2C3.pdf

9 Pasal 1 butir 7, UU No. 4 Tahun 2009 tentang Pertambangan Mineral dan Batubara.
} 
atau Bupati/Walikota sesuai dengan kewenangannya. IUP diberikan kepada $:^{10}$

1. Badan usaha, yang dapat berupa badan usaha swasta, Badan Usaha Milik Negara, atau Badan Usaha Milik Daerah;

2. Koperasi; dan

3. Perseorangan, yang dapat berupa orang perseorangan yang merupakan warga Negara Indonesia, Perusahaan Firma, atau Perusahaan Komanditer.

Pemberian Izin Usaha Pertambangan (IUP) akan dilakukan setelah diperolehnya WIUP (Wilayah Izin Usaha Pertambangan). Dalam satu WIUP dimungkinkan untuk diberikan 1 IUP maupun beberapa IUP. Pasal 36 UU Minerba membagi IUP ke dalam dua tahap, yakni :

1. IUP eksplorasi, yang meliputi kegiatan penyelidikan umum, eksplorasi, dan studi kelayakan; dan

2. IUP Operasi Produksi, yang meliputi kegiatan konstruksi, penambangan, pengolahan dan pemurnian, serta pengangkutan dan penjualan.

Pasal 39 UU Minerba mengatur bahwa IUP Eksplorasi wajib memuat ketentuan sekurangkurangnya : ${ }^{11}$

a. Nama perusahaan;

b. Lokasi dan luas wilayah;

c. Rencana umum tata ruang;

d. Jaminan kesungguhan;

e. Modal investasi;

f. Perpanjangan waktu tahap kegiatan;

g. Hak dan kewajiban pemegang IUP;

h. Jangka waktu berlakunya tahap kegiatan;

i. Jenis usaha yang diberikan;

j. Rencana pengembangan dan pemberdayaan masyarakat di sekitar wilayah pertambangan;

k. Perpajakan;

I. Penyelesaian perselisihan;

m. Iuran tetap dan iuran eksplorasi; dan

n. Amdal. $^{12}$

\footnotetext{
${ }^{10}$ Philipus M. Hadjon, dkk, Pengantar Hukum Administrasi Negara, Gadjah Mada University Press, Yogyakarta, 2008, hal. 100.

11 Hukumpertambangan.com (2011). Izin Usaha Pertambangan. hal.1 https://www.hukumpertambangan.com/izin-usaha/izinusaha-pertambangan/

${ }^{12}$ Siti Sundari Rangkuti, Hukum Lingkungan dan Kebijakan LingkunganDalam Proses Pembangunan Hukum Nasional, Disertasi, Surabaya, 2008, hal. 90.
}

Sedangkan untuk Izin Usaha Pertambangan (IUP) Operasi Produksi wajib memuat ketentuan sekurang-kurangnya $:^{13}$

a. Nama perusahaan;

b. Luas wilayah;

c. Lokasi penambangan;

d. Lokasi pengolahan dan pemurnian;

e. Pengangkutan dan penjualan;

f. Modal investasi;

g. Jangka waktu berlakunya IUP;

h. Jangka waktu tahap kegiatan;

i. Penyelesaian masalah pertanahan;

j. Lingkungan hidup termasuk reklamasi dan pascatambang;

k. Dana jaminan reklamasi dan pascatambang;

I. Perpanjangan IUP;

m. Hak dan kewajiban pemegang IUP;

n. Rencana pengembangan dan pemberdayaan masyarakat di sekitar wilayah pertambangan;

o. Perpajakan;

p. Penerimaan negara bukan pajak yang terdiri atas iuran tetap dan iuran produksi;

q. Penyelesaian perselisihan;

r. Keselamatan dan kesehatan kerja;

s. konservasi mineral atau batubara;

t. Pemanfaatan barang, jasa, dan teknologi dalam negeri;

u. Penerapan kaidah keekonomian dan keteknikan pertambangan yang baik;

v. Pengembangan tenaga kerja Indonesia;

w. Pengelolaan data mineral atau batubara; dan

x. Penguasaan, pengembangan, dan penerapan teknologi pertambangan mineral atau batubara.

Pasal 40 UU Minerba diatur bahwa IUP diberikan terbatas pada 1 jenis mineral atau batubara. Dalam hal pemegang IUP menemukan mineral lain dalam WIUP yang dikelolanya, maka pemegang IUP tersebut mendapatkan prioritas untuk mengusahakan mineral yang ditemukannya. Sebelum pemegang IUP tersebut mengusahakan mineral lain yang ditemukannya, diatur bahwa pemegang IUP tersebut wajib mengajukan permohonan IUP baru kepada Menteri, gubernur, bupati/walikota sesuai dengan kewenangannya masing-masing. Dalam hal

${ }^{13}$ Ibid, hal. 2. 
pemegang IUP tersebut tidak berminat untuk mengusahakan mineral lain yang ditemukannya, maka pemegang IUP tersebut memiliki kewajiban untuk menjaga mineral tersebut agar tidak dimanfaatkan pihak lainnya yang tidak berwenang.

Terhadap izin Usaha Pertambangan (IUP) eksplorasi merupakan izin yang diberikan untuk kegiatan penyelidikan umum, eksplorasi, dan studi kelayakan dalam rangka pertambangan. Hal ini diatur melalui Pasal 29 Peraturan Pemerintah No. 23 Tahun 2010 tentang Pelaksanaan Kegiatan Usaha Pertambangan Mineral dan Batubara (PP 23/2010), bahwa IUP eksplorasi diberikan berdasarkan permohonan dari badan usaha, koperasi, dan perseorangan yang telah mendapatkan Wilayah Izin Usaha Pertambangan (WIUP). ${ }^{14}$ Dalam hal kegiatan eksplorasi dan kegiatan studi kelayakan, pemegang IUP eksplorasi yang mendapatkan mineral atau batubara yang tergali wajib melaporkan kepada pemberi IUP.

Persyaratan Untuk Memperoleh IUP Eksplorasi

Pasal 23 PP 23/2010 mengatur bahwa persyaratan IUP Eksplorasi meliputi persyaratan, sebagai berikut :

1. Administratif;

2. Teknis;

3. Lingkungan; dan

4. Finansial

A. Persyaratan administratif sebagaimana dimaksud dalam huruf a untuk badan usaha meliputi :

a. Untuk IUP Eksplorasi mineral logam dan batubara:

1. Surat permohonan;

2. Susunan direksi dan daftar pemegang saham; dan

3. Surat keterangan domisili.

b. Untuk IUP Eksplorasi mineral bukan logam dari batuan:

1. Surat permohonan;

2. Profil badan usaha;

3. Akta pendirian badan usaha yang bergerak di bidang usaha pertambangan yang telah disahkan oleh pejabat yang berwenang;

\footnotetext{
14 Pasal 29 Peraturan Pemerintah No.23 Tahun 2010 tentang Pelaksanaan Kegiatan Usaha Pertambangan Mineral dan Batubara (PP 23/2010).
}

4. Nomor pokok wajib pajak;

5. Susunan direksi dan daftar pemegang saham; dan

6. Surat keterangan domisili.

Persyaratan administratif sebagaimana dimaksud dalam huruf a untuk koperasi meliputi : ${ }^{15}$

a. Untuk IUP Eksplorasi mineral logam dan batubara:

1. Surat permohonan;

2. Susunan pengurus; dan

3. Surat keterangan domisili.

b. Untuk IUP Eksplorasi mineral bukan logam dan batuan:

1. Surat permohonan;

2. Profil koperasi;

3. Akta pendirian koperasi yang bergerak di bidang usaha pertambangan yang telah disahkan oleh pejabat yang berwenang;

4. Nomor pokok wajib pajak;

5. Susunan pengurus; dan

6. Surat keterangan domisili.

Persyaratan administratif sebagaimana dimaksud dalam huruf a untuk orang perseorangan, meliputi:

a. Untuk IUP Eksplorasi mineral logam dan batubara:

1. Surat permohonan; dan

2. Surat keterangan domisili.

b. Untuk IUP Eksplorasi mineral bukan logam dan batuan:

1. Surat permohonan;

2. Kartu tanda penduduk;

3. Nomor pokok wajib pajak; dan

4. Surat keterangan domisili.

Persyaratan administratif sebagaimana dimaksud dalam huruf a untuk perusahaan firma dan perusahaan komanditer meliputi

a. Untuk IUP Eksplorasi mineral logam dan batubara:

1. Surat permohonan;

2. Susunan pengurus dan daftar pemegang saham; dan

3. Surat keterangan

b. Untuk IUP Eksplorasi mineral bukan logam dari batuan:

1. Surat permohonan;

\footnotetext{
${ }^{15}$ Saiful Anwar, Sendi-sendi Hukum Administrasi Negara, Glora Madina Press, Jakarta, 2004, hal. 78.
} 
2. Profil perusahaan;

3. Akta pendirian yang bergerak dibidang usaha pertambangan;

4. Nomor pokok wajib pajak;

5. Susunan pengurus dan daftar pemegang saham; dan

6. Surat keterangan domisili.

B. Persyaratan teknis sebagaimana dimaksud dalam huruf $b$ untuk IUP Eksplorasi, meliputi:

1. Daftar riwayat hidup dan surat pernyataan tenaga pertambangan dan/atau geologi yang berpengalaman paling sedikit 3 (tiga) tahun;

2. Peta WIUP yang dilengkapi dengan batas koordinat geografis lintang dan bujur sesuai dengan ketentuan sistem informasi geografi yang berlaku secara nasional,

C. Persyaratan lingkungan sebagaimana dimaksud dalam huruf $\mathrm{c}$ untuk IUP Eksplorasi meliputi pernyataan untuk mematuhi ketentuan peraturan perundang-undangan di bidang perlindungan dan pengelolaan lingkungan hidup.

D. Persyaratan finansial sebagaimana dimaksud dalam huruf $d$ untuk IUP Eksplorasi, meliputi :

1. Bukti penempatan jaminan kesungguhan pelaksanaan kegiatan eksplorasi; dan

2. Bukti pembayaran harga nilai kompensasi data informasi hasil lelang WIUP mineral logam atau batubara sesuai dengan nilai penawaran lelang atau bukti pembayaran biaya pencadangan wilayah dan pembayaran pencetakan peta WIUP mineral bukan logam atau batuan atas permohonan wilayah.

Pada bagian sebelumnya telah dijelaskan mengenai Izin Usaha Pertambangan (IUP) seperti yang telah diatur pada Pasal 1 (7) UU No. 4 Tahun 2009 tentang Pertambangan Mineral dan Batubara bahwa, Izin Usaha Pertambangan (IUP) adalah izin yang diberikan untuk melaksanakan usaha pertambangan, dan Pemberian Izin Usaha Pertambangan (IUP) akan dilakukan setelah diperolehnya WIUP (Wilayah Izin Usaha Pertambangan), dimana dalam satu
WIUP dimungkinkan untuk diberikan 1 IUP maupun beberapa IUP. ${ }^{16}$

Pasal 1 ayat 30 UU No. 4 Tahun 2009 tentang Pertambangan Mineral dan Batubara (UU Minerba), mengatur bahwa $:{ }^{17}$ Wilayah Usaha Pertambangan (WUP) adalah bagian dari Wilayah Pertambangan (WP) yang telah memiliki ketersediaan data, potensi, dan/atau informasi geologi. Wilayah Pertambangan sendiri ialah wilayah yang memiliki potensi mineral dan/atau batubara dan tidak terikat dengan batasan administrasi pemerintahan yang merupakan bagian dari tata ruang nasional.

Dengan demikian merupakan kewenangan Pemerintah dalam pengelolaan pertambangan mineral dan batubara bagi kepentingan khalayak banyak, untuk menetapkan Wilayah Pertambangan. Pasal 14 UU Minerba mengatur bahwa penetapan Wilayah Pertambangan akan dilakukan setelah Pemerintah berkoordinasi dengan Pemerintah Daerah, berdasarkan data yang dimiliki oleh kedua belah pihak, dan disampaikan secara tertulis kepada Dewan Perwakilan Rakyat. Sebagian kewenangan Pemerintah Pusat dapat dilimpahkan kepada pemerintah provinsi. Pemerintah pusat dan daerah wajib untuk terus mengadakan penginventarisasian, penyelidikan, penelitian serta eksplorasi pertambangan dalam rangka penyiapan Wilayah Pertambangan. ${ }^{18}$

Selanjutnya dalam Pasal 16 UU Minerba diatur bahwa satu Wilayah Usaha Pertambangan (WUP) terdiri dari 1 atau beberapa Wilayah Ijin Usaha Pertambangan (WIUP) yang berada pada lintas wilayah provinsi dan/atau kabupaten/kota.

Terdapat beberapa kriteria untuk menetapkan satu atau beberapa WIUP, yakni $:^{19}$

a. Letak geografis;

b. Kaidah konservasi;

c. Daya dukung lindungan lingkungan;

16 Salim, HS, Hukum Pertambangan Mineral dan Batu Bara, Sinar Grafika, Jakarta, 2014, hal. 11.

17 Pasal 1 ayat 30 UU No. 4 Tahun 2009 tentang Pertambangan Mineral dan Batubara (UU Minerba).

18 Salim, HS, Hukum Pertambangan di Indonesia, PT. RajaGrafindo Persada, Jakarta, 2014, hal. 134.

19 Hukumpertambangan.com (2011). Wilayah Usaha Pertambangan Mineral dan Batubara https://www.hukumpertambangan.com/wilayahusaha/wilayah-usaha-pertambangan-mineral-danbatubara/ 
d. Optimalisasi sumber daya mineral dan/atau batubara; dan

e. Tingkat kepadatan penduduk.

Tata Cara Perolehan Wilayah Ijin Usaha Pertambangan (WIUP) Mineral Logam dan Batubara, dalam Pasal 8 (3) Peraturan Pemerintah No. 23 Tahun 2010 Tentang Pelaksanaan Kegiatan Usaha Pertambangan Mineral dan Batubara (“PP.23/2010"), WIUP mineral logam dan batubara diperoleh dengan cara lelang. Setiap pemohon, mencakup badan usaha, koperasi dan perseorangan; hanya akan diberikan satu WIUP. Namun jika pemohon merupakan badan usaha yang telah go public, maka badan usaha tersebut dapat diberikan lebih dari satu WIUP. Menteri, gubernur, atau bupati/walikota akan mengumumkan pelelangan secara terbuka dalam jangka waktu paling lambat 3 bulan sebelum pelelangan.

Pasal 13 PP 23/2010 mengatur persyaratan yang harus dipenuhi oleh peserta lelang untuk mengikuti lelang. Peserta lelang harus memenuhi persyaratan administratif, teknis dan finansial. Persyaratan administratif mencakup antara lain $:^{20}$

1. Pengisian formulir yang sudah disiapkan panitia lelang;

2. Pencantuman profil badan usaha beserta akta pendirian masing-masing; dan

3. Nomor pokok wajib pajak.

Persyaratan teknis meliputi :

1. Pengalaman badan usaha, koperasi, atau perseorangan di bidang pertambangan mineral atau batubara paling sedikit 3 tahun, atau bagi perusahaan baru harus mendapat dukungan dari perusahaan induk, mitra kerja, atau afiliasinya yang bergerak di bidang pertambangan;

2. Dimilikinya paling sedikit 1 orang tenaga ahli dalam bidang pertambangan dan/atau geologi yang berpengalaman paling sedikit 3 tahun; dan

3. Rencana kerja dan anggaran biaya untuk kegiatan 4 tahun eksplorasi.

Persyaratan finansial meliputi :

1. Laporan keuangan tahun terakhir yang sudah diaudit akuntan publik;

2. Penempatan jaminan kesungguhan lelang dalam bentuk uang tunai di bank

\footnotetext{
${ }^{20}$ Eny Kusdarini, Dasar-dasar Hukum Administrasi Negara dan Asas-asas Umum Pemerintahan Yang Baik, UNY Press, Yogyakarta, 2011, hal. 88.
}

pemerintah sebesar 10\% (sepuluh persen) dari nilai kompensasi data informasi atau dari total pengganti investasi untuk lelang WIUP yang telah berakhir; dan

3. Pernyataan bersedia membayar nilai lelang WIUP dalam jangka waktu paling lambat 5 (lima) hari kerja, setelah pengumuman pemenang lelang.

\section{B. Implementasi Hukum Terhadap Pemberian Izin Usaha Bisnis Pertambangan Mineral dan Batubara di Indonesia}

Pada uraian sebelumnya telah dijelaskan bahwa Izin usaha Pertambangan adalah pemberian izin untuk melakukan usaha pertambangan kepada orang pribadi atau badan yang diberikan oleh Pemerintah Pusat dengan berkoordinasi dengan Pemerintah Daerah. Izin Usaha Pertambangan diberikan dalam bentuk surat keputusan Izin Usaha Pertambangan.

Izin Usaha Pertambangan terdiri atas dua tahap

1. Izin Usaha Pertambangan Eksplorasi meliputi kegiatan penyelidikan umum, eksplorasi, dan studi kelayakan.

2. Izin Usaha Pertambangan Operasi Produksi meliputi kegiatan konstruksi, penambangan, pengolahan dan pemurnian, serta pengangkutan dan penjualan. $^{21}$

Pemegang Izin Usaha Pertambangan Eksplorasi dan pemegang Izin Usaha Pertambangan Operasi Produksi dapat melakukan sebagian atau seluruhnya.

Izin Usaha Pertambangan diberikan oleh :

1. Bupati/Walikota apabila Wilayah Izin Usaha Pertambangan berada di dalam satu wilayah kabupaten/kota;

2. Gubernur apabila Wilayah Izin Usaha Pertambangan berada pada lintas wilayah kabupaten/kota dalam 1 provinsi setelah mendapatkan rekomendasi dari Bupati/ Walikota setempat sesuai dengan ketentuan peraturan perundangundangan.

\footnotetext{
$21 \quad$ Bonkadhafadli.blogspot.com (2013). Prosedur Pengurusan Izin Usaha Pertambangan Propinsi Sumatera Utara.

https://bonkadhafadli.blogspot.com/2013/04/prosedurpengurusan-izin-usaha.html
} 
3. Menteri apabila Wilayah Izin Usaha Pertambangan berada pada lintas wilayah provinsi setelah mendapatkan rekomendasi dari Gubernur dan Bupati/Walikota setempat sesuai dengan ketentuan peraturan perundangundangan.

Izin Usaha Pertambangan diberikan kepada :

1. Badan usaha.

2. Koperasi.

3. Perseorangan.

Izin Usaha Pertambangan Eksplorasi meliputi kegiatan Penyelidikan umum, Eksplorasi, dan Study kelayakan wajib memuat ketentuan sekurang kurangnya :
a) Nama perusahaan.
b) Lokasi dan luas wilayah.
c) Rencana umum tata ruang.
d) Jaminan kesungguhan.
e) Modal investasi.
f) Perpanjangan waktu tahap kegiatan.
g) Hak dan kewajiban pemegang Izin Usaha Pertambangan.
h) Jangka waktu berlakunya tahap kegiatan.
i) Jenis usaha yang diberikan.
j) Rencana pengembangan dan pemberdayaan masyarakat di sekitar wilayah pertambangan.
k) Perpajakan.
l) Penyelesaian perselisihan.
m) luran tetap dan iuran eksplorasi.
n) Amdal.

Izin Usaha Pertambangan Operasi Produksi meliputi kegiatan Konstruksi, Penambangan, Pengolahan dan Pemurnian wajib memuat ketentuan sekurang - kurangnya :

1. Nama perusahaan.

2. Luas wilayah.

3. Lokasi penambangan.

4. Lokasi pengolahan dan pemurnian.

5. Pengangkutan dan penjualan.

6. Modal investasi.

7. Jangka waktu berlakunya Izin Usaha Pertambangan.

8. Jangka waktu tahap kegiatan.

9. Penyelesaian masalah pertanahan.

10. Lingkungan hidup termasuk reklamasi dan pasca tambang.

11. Dana jaminan reklamasi dan pasca tambang.

12. Perpanjangan Izin Usaha
13. Hak dan kewajiban pemegang Izin Usaha Pertambangan.

14. Rencana pengembangan dan pernberdayaan masyarakat di sekitar wilayah pertambangan.

15. Perpajakan.

16. Penerimaan negara bukan pajak yang terdiri atas iuran tetap dan iuran produksi.

17. Penyelesaian perselisihan.

18. Keselamatan dan kesehatan kerja.

19. Konservasi mineral atau batubara.

20. Pemanfaatan barang, jasa, dan teknologi dalam negeri.

21. Penerapan kaidah keekonomian dan keteknikan pertambangan yang baik.

22. Pengembangan tenaga kerja Indonesia.

23. Pengelolaan data mineral atau batubara. 22

24. Penguasaan, pengembangan, dan penerapan teknologi pertambangan mineral atau batubara.

Izin Usaha Pertambangan Eksplorasi meliputi kegiatan Penyelidikan umum, Eksplorasi, dan Study kelayakan Izin Usaha Pertambangan diberikan untuk satu jenis mineral atau batubara. Pemegang Izin Usaha Pertambangan Eksplorasi meliputi kegiatan Penyelidikan umum, Eksplorasi, dan Study kelayakan Izin Usaha Pertambangan. Menemukan mineral lain di dalam Wilayah Izin Usaha Pertambangan yang dikelola diberikan prioritas untuk mengusahakannya.

Pemegang Izin Usaha Pertambangan mengusahakan mineral adalah Izin Usaha Pertambangan Operasi Produksi meliputi kegiatan Konstruksi, Penambangan, wajib mengajukan permohonan Izin Usaha Pertambangan baru kepada Menteri, Gubernur, dan Bupat/Walikota sesuai dengan kewenangannya. Pemegang Izin Usaha Pertambangan Operasi Produksi meliputi kegiatan Konstruksi, Penambangan, dapat menyatakan tidak berminat untuk mengusahakan mineral lain yang ditemukan tersebut.

Pemegang Izin Usaha Pertambangan yang tidak berminat untuk mengusahakan mineral lain yang ditemukan wajib menjaga mineral lain tersebut agar tidak dimanfaatkan pihak lain.

22 Philipus M. Hadjon, Pengantar Hukum Perizinan, Yuridika, Surabaya, 1993, hal. 12. 
Izin Usaha Pertambangan untuk mineral lain dapat diberikan kepada pihak lain oleh Menteri, Gubernur, dan Bupati / Walikota sesuai dengan kewenangannya.

2. Izin Usaha Pertambangan Eksplorasi

Izin Usaha Pertambangan Eksplorasi untuk pertambangan mineral logam dapat diberikan dalam jangka waktu paling lama delapan tahun. Izin Usaha Pertambangan Eksplorasi untuk pertambangan mineral bukan logam dapat diberikan paling lama dalam jangka waktu tiga tahun dan mineral bukan logam jenis tertentu dapat diberikan dalam jangka waktu paling lama tujuh tahun.

Izin Usaha Pertambangan Eksplorasi untuk pertambangan batuan dapat diberikan dalam jangka waktu paling lama tiga tahun. Izin Usaha Pertambangan Eksplorasi untuk pertambangan batubara dapat diberikan dalam jangka waktu paling lama tujuh tahun.

Didalam hal kegiatan Eksplorasi dan kegiatan studi kelayakan, pemegang Izin Usaha Pertambangan Eksplorasi yang mendapatkan mineral atau batubara yang tergali wajib melaporkan kepada pemberi Izin Usaha Pertambangan. Pemegang Izin Usaha Pertambangan Eksplorasi yang ingin menjual mineral atau batubara wajib mengajukan izin sementara untuk melakukan pengangkutan dan penjualan Izin sementara yang diberikan oleh Menteri, Gubernur, atau Bupati / Walikota sesuai dengan kewenangannya.

Mineral atau batubara yang tergali dalam hal kegiatan ekpolorasi dan kegiatan study kelayakan, pemegang Izin Usaha Pertambangan Ekplorasi yang mendapatkan mineral atau batubara yang tergali wajib melaporkan kepeda pemberi Izin Usaha Pertambangan dikenai iuran produksi.

3. Izin Usaha Pertambangan Operasi Produksi.

Izin Usaha Pertambangan Operasi Produksi adalah izin usaha yang diberikan setelah selesai pelaksanaan Izin Usaha Pertambangan Eksplorasi untuk melakukan tahapan kegiatan operasi produksi. Setiap pemegang Izin Usaha Pertambangan Eksplorasi dijamin untuk memperoleh Izin Usaha Pertambangan Operasi Produksi sebagai kelanjutan kegiatan usaha pertambangannya. Izin Usaha Pertambangan Operasi Produksi dapat diberikan kepada badan usaha, koperasi, atau perseorangan atas hasil pelelangan.
Pertambangan Tanpa Izin adalah usaha pertambangan yang dilakukan oleh perseorangan, sekelompok orang, atau perusahaan yayasan berbadan hukum yang dalam operasinya tidak memiliki Izin dari instansi pemerintah sesuai peraturan perundang-undangan yang berlaku. Dengan demikian, izin, rekomendasi, atau surat berbentuk apapun yang diberikan kepada perseorangan, sekelompok orang, perusahaan atau yayasan oleh instansi pemerintah di luar ketentuan peraturan perundang - undangan yang berlaku, dapat dikategorikan sebagai Pertambangan Tanpa Izin.

Izin Pertambangan Rakyat, yang selanjutnya disebut IPR, adalah izin untuk melaksanakan usaha pertambangan dalam wilayah pertambangan rakyat dengan luas wilayah dan investasi yang terbatas.

\section{PENUTUP}

\section{A. Kesimpulan}

1. Pengaturan hukum terhadap pengelolaan pemberian ijin usaha bisnis pertambangan mineral dan batubara di Indonesia, melalui Pasal 1 (7) UU No.4 Tahun 2009 tentang Pertambangan Mineral dan Batubara bahwa, berkaitan dengan Izin Usaha Pertambangan (IUP), juga melalui Pasal 6 Peraturan Pemerintah No.23 Tahun 2010 tentang Pelaksanaan Kegiatan Usaha Pertambangan Mineral dan Batubara (dikenal sebagai PP 23 Tahun 2010) yang mengatur bahwa IUP diberikan oleh Menteri, Gubernur, atau Bupati/Walikota sesuai dengan kewenangannya.

2. Implementasi terhadap pemberian izin usaha bisnis pertambangan mineral dan batubara di Indonesia yaitu melalui pemberian izin untuk melakukan usaha pertambangan kepada orang pribadi atau badan yang diberikan oleh Pemerintah Pusat dengan berkoordinasi dengan Pemerintah Daerah. Izin Usaha Pertambangan diberikan dalam bentuk surat keputusan Izin Usaha Pertambangan, yang terdiri atas dua tahap: Izin Usaha Pertambangan Eksplorasi dan Izin Usaha Pertambangan Operasi Produksi.

\section{B. Saran}


1. Meskipun dalam Pasal 40 UU Minerba diatur bahwa IUP diberikan terbatas pada satu (1) jenis mineral atau batubara, apabila pemegang IUP menemukan mineral lain dalam WIUP yang dikelolanya, maka sebaiknya pemegang IUP tersebut mengusahakan mineral yang telah ditemukannya, dengan terlebih dahulu mengajukan permohonan IUP baru kepada Menteri, gubernur, bupati/walikota sesuai dengan kewenangannya masing-masing.

2. Untuk mengetahui dengan baik dan meningkatkan potensi pertambangan di daerah/wilayahnya, maka sebaiknya Pemerintah Daerah berkoordinasi dengan Pemerintah Pusat, terutama untuk sinkronisasi data yang dimiliki oleh kedua belah pihak, yang disampaikan secara tertulis kepada Dewan Perwakilan Rakyat. Demikian juga sebagian kewenangan Pemerintah Pusat dapat dilimpahkan kepada pemerintah provinsi, dimana keduanya sebaiknya terus mengadakan penginventarisasian, penyelidikan, penelitian serta eksplorasi pertambangan dalam rangka penyiapan wilayah dan peningkatan potensi pertambangan nasional.

\section{DAFTAR PUSTAKA}

Abdul Rasyid Saliman, Hukum Bisnis Untuk Perusahaan, Teori dan Contoh Kasus, PrenadaMedia, Jakarta, 2005.

Adrian Sutedi, Hukum Perijinan Dalam Sektor Pelayanan Publik, Sinar Grafika, Jakarta, 2010.

Almaida, (2008). Upaya Pengolahan Lingkungan Kegiatan Pertambangan. https://muktiarsandi.wordpress.com/201 6/06/15/upaya-pengolahan-lingkungankegiatan...

Bonkadhafadli.blogspot.com (2013). Prosedur Pengurusan Izin Usaha Pertambangan Propinsi Sumatera Utara. https://bonkadhafadli.blogspot.com/2013/ 04/prosedur-pengurusan-izin-usaha.html

Budi Untung, Hukum dan Etika Bisnis, Andi, Yogyakarta, 2012

Dwi Haryadi, Pengantar Hukum Pertambangan Mineral dan Batu Bara, UBB Press, Kampus Terpadu Universitas Bangka Belitung, 2018.
Eny Kusdarini, Dasar-dasar Hukum Administrasi Negara dan Asas-asas Umum Pemerintahan Yang Baik, UNY Press, Yogyakarta, 2011.

Gatot Supramono, Hukum Pertambangan Mineral dan Batu Bara di Indonesia, Rineka Cipta, Jakarta, 2012.

Hasibuan, Puspa Melati. (2006). Dampak Penambangan Bahan GalianGolongan C terhadap Lingkungan Sekitarnya di Kabupaten Deli Serdang. eprints.undip.ac.id/36437/2/Bab_1\%2C2\% 2C3.pdf.

Jeff Madura, Pengantar Bisnis (Terjemahan), Salemba Empat, Jakarta, 2007.

Miranti Kurnia Ningsih Muntaha (2019). Reklamasi Lahan Pascatambang. Prodi Teknik Pertambangan Universitas Khairun Ternate. https://news.detik.com/kolom/d4765654/reklamasi-lahan-pascatambang.

Moh. Faisal Salam, Pertumbuhan Hukum Bisnis di Indonesia, Pradnya Paramita, Jakarta, 2001.

Nirahua Salmon, Hukum Perizinan "Pengelolaan Sumber Daya Alam di Wilayah Laut Daerah", Rajawali Perss, Jakarta, 2013.

Philipus M. Hadjon, Pengantar Hukum Perizinan, Yuridika, Surabaya, 1993.

Philipus M. Hadjon, dkk, Pengantar Hukum Administrasi Negara, Gadjah Mada University Press, Yogyakarta, 2008.

Saiful Anwar, Sendi-sendi Hukum Administrasi Negara, Glora Madina Press, Jakarta, 2004.

Salim, HS, Hukum Pertambangan di Indonesia, PT. RajaGrafindo Persada, Jakarta, 2014.

Siti Sundari Rangkuti, Hukum Lingkungan dan Kebijakan LingkunganDalam Proses Pembangunan Hukum Nasional, Disertasi, Surabaya, 2008.

Soerjani (2007). makalah tentang iptek dalam bidang pertambangan. https://id.scribd.com/doc/297195867/ma kalah.

Sudrajat (2010), Tentang Tata Kelola Pertambangan, https://jvccomputer.blogspot.com/2015/0 7/makalah-tentang-tata-kelolapertambangan.html.

Tri Hayati, Era Baru Hukum Pertambangan di bawah Rezim UU No. 4Tahun 2009, Cet.1, 
Lex Et Societatis Vol. VIII/No. 4/Okt-Des/2020

Yayasan Pustaka, Obor Indonesia, Jakarta, 2015.

Y. Sri Pudyatmoko, Perizinan Problem dan Upaya Pembenahan, Grafsindo, Jakarta, 2009. 